\title{
Mongolian crude propolis content analysis and antioxidant activity
}

\author{
Ichinkhorloo P. ${ }^{1}$, Gantsetseg G. ${ }^{1}$, Selenge Kh. ${ }^{2}$, Undrakhbayar Ts. ${ }^{2}$, Otgonsugar P. ${ }^{2}$, \\ Bat-Erdem B. ${ }^{2}$, Munkhjargal B. ${ }^{1}$, Byambajav Ts. ${ }^{2}$, Undarmaa T. ${ }^{2 *}$ \\ 1-School of Arts and Sciences, National University of Mongolia, Ulaanbaatar, Mongolia \\ 2-Institute of Veterinary Medicine, Mongolian University of Life Sciences, Ulaanbaatar, Mongolia \\ *Corresponding author: tundarmaa@gmail.com
}

\begin{abstract}
Propolis, a precious bee product has been widely used for pharmaceutical purposes for centuries. Chemical components, properties, and activities are differed based on geographic origins, respective plant sources, and bee species. In our research, Mongolian propolis from 2 different places was examined for chemical content and antioxidant effect. The samples were collected from Northern and Central parts of Mongolia and were examined for a total of 8 contents. Crude Mongolian propolis sample from the central part of Mongolia displayed higher results in every aspect with total moisture of $2.1 \%$; ash $1.7 \%$; fat $67.8,69.3 \%$; and $1.05 \%$ of protein. The free amino acid in $70 \% \mathrm{EtOH}$ was higher in the sample from the northern part with $1.21 \mu \mathrm{g} / \mathrm{mg}$ and the total amino acid was quantified by HPLC and highest concentration detected in methionine $1.90 \mathrm{mg} / \mathrm{g}$, and $2.62 \mathrm{mg} / \mathrm{g}$. Totally 3 alkaloids and 2 phenolics were detected by TLC and high antioxidant activity was presented in DPPH radical scavenging test. The results suggest that the best solvent for propolis samples is EtOH $70 \%$ solution. The test propolis samples contain different types of alkaloids and phenolics, have a high amount of methionine and have a moderate-high antioxidant effect.
\end{abstract}

KEYWORDS: Mongolian propolis, bee glue, chemical constituent

\section{INTRODUCTION}

Propolis is very rich in natural compounds and the main unique characteristic is the chemical components, properties, and activities are different based on geographic origins, respective plant sources, and bee species. Overall, more than 420 compounds were determined and the main constituents are resin, oil, wax, and pollen. It also contains various amino acids, minerals, vitamins and different types of secondary metabolites such as flavonoids, phenols, and aromatic compounds. Due to numerous bioactive compounds, propolis has a wide range of effects: antioxidant, antibacterial, antifungal, antiviral, antiinflammatory, immunomodulatory, antitumor, and hepatoprotective activity $[1,2]$.

Propolis, which is known as bee glue is a natural resinous product collected by honey bees from plants

\section{MATERIALS AND METHOD}

\section{Sample preparation}

In our research, two crude propolis samples were collected from Selenge province (S1), northern part and Ulaanbaatar city, central part of Mongolia during August 2018. Before the experiments, propolis samples were kept in lightless condition at $-20^{\circ} \mathrm{C}$ to build their hives. The human beings started to use propolis back in ancient times around 300BC in folk medicine. In various traditional medicines, propolis was used in wound treatment, mouth disinfection, eczemas, myalgia and rheumatism, tuberculosis. Nowadays, in many countries, it is used as a component in pharmaceutical, cosmetic and food supplements [3].

The bee industry in Mongolia has been developing since 1959. During the last decade, there was a significant increase in bee products. However, all attention was paid to honey rather than propolis, which is also a precious natural compound. The following research is to examine propolis collected from different parts of Mongolia in component determination and bioactive effect discovery.

degree. For the determination of the total moisture, ash, fat, and protein the crude propolis samples were used directly.

\section{Sample extraction}

Samples were homogenized in an ultrasonic bath for 20 minutes and then extracted using the shaker at 
$22^{\circ} \mathrm{C}$ in different hours and solutions, including $\mathrm{ddH}_{2} 0,96 \% \mathrm{MeOH}, 10-96 \% \mathrm{EtOH}$. Later solutions were vacuum filtered, evaporated using a vacuum rotary evaporator, and freeze-dried.

\section{Total Moisture Content}

Loss on Drying or moisture content was determined by the standard method AOAC Method 934.01 with slight modification as described by the Dias and et all [4]. A sample of 1 gram was dried in the mechanical convection oven at $105^{\circ} \mathrm{C}$ for 3 hours and was cooled in a desiccator to room temperature and weighed again for the test. The procedure was repeated several times to stabilize the weight of propolis. Final calculations were made by the equation provided in the assay.

\section{Total Ash Content}

Analysis of total ash content was performed according to AOAC Official Method 920.181 with minor modification [4]. An empty crucible was incubated at $600^{\circ} \mathrm{C}$ for 1 hour and cooled down to room temperature in a desiccator and later weighed until it became stable. Then $0.5 \mathrm{~g}$ of propolis sample was added to the crucible and was lightly burned until the smoke has been disappeared. After this, the sample underwent calcination at $600^{\circ} \mathrm{C}$ for 1 hour. At last, the crucible with the burned sample was cooled down to room temperature and weighed for the determination. The results were expressed in percentage by a formula.

\section{Total Fat Content}

For the total fat content, the Soxhlet method was used based on the Soxhlet Extraction of Crude Fat (AOAC Official Method 960.39) with small modification [5]. The total amount of $0.5 \mathrm{~g}$ of dehydrated propolis sample was taken to determine the total fat content. First, the sample was extracted in an organic solvent in the Soxhlet apparatus and later the solvent was evaporated. Secondly, the sample was put onto the filter paper and weighed. Thirdly, the sample with filter paper was put into the Soxhlet apparate and the extraction flask was $3 / 4$ filled with hexane and boiled for 8 hours. The sample was put into a fume hood and organic solvent was evaporated. At last, the sample was incubated in a drying oven at $100^{\circ} \mathrm{C}$ for $10 \mathrm{~min}$. The sample weights were witnessed and put into the formula.

\section{RESULTS}

The extracted fraction's solutes were examined by refractometer and the 70\% EtOH solution incubated for 24 hours showed the highest result with 5\% (Table

\section{Total Protein Content}

Total protein content and nitrogen-containing compounds of propolis were determined with a slight modification of Kjeldahl's method according to 981.10 of the AOAC International [6]. For the total protein content of the propolis, a minor modification was made to the original method. An amount of $0.5 \mathrm{~g}$ of the sample was put with $\mathrm{H}_{2} \mathrm{SO}_{4}$ and for catalyzation purposes, $\mathrm{HClO} 4$ was used. For the titration were used $1 \mathrm{~N} \mathrm{HCl}$ and the amount of total protein in the sample material was multiplied with the traditional conversion factor of 6.25 . The final results were calculated formula cited in the assay.

\section{The free amino acid content}

A colorimetric assay was used to determine free amino acid content. Freeze-dried propolis of $0.01 \mathrm{~g}$ was extracted in $20 \mathrm{ml}$ of EtOH. Next, the $1 \mathrm{ml}$ ninhydrin solution was added and incubated in a water bath at $60^{\circ} \mathrm{C}$ for 20 minutes and cooled down to room temperature. After $5 \mathrm{ml}$ of $50 \%$ of $\mathrm{EtOH}$ were added to the sample and incubated in lightless condition for 10 minutes. The light absorbance was measured at $570 \mathrm{~nm}$. The final data were calculated by comparison between a standard curve from leucine [7].

\section{Total Amino Acid Content}

Total amino acid containment was measured by HPLC, Shimadzu at the China-Mongolia joint laboratory of applied molecular biology, Ulaanbaatar, Mongolia.

\section{Total Phenolics and Alkaloids}

Total phenolics and alkaloids were determined using TLC with system Toluene, Methanol, Acetone Ammonia (50:40:8:2). Dragendorff reagent was used for alkaloids and $5 \% \mathrm{H}_{2} \mathrm{SO}_{4}$ was sprayed to identify phenolic compounds.

\section{Antioxidant Effect}

The antioxidant effect was determined by colorimetric DPPH radical scavenging assay. The results were compared with butylated hydroxytoluene (BHT), which is a high antioxidant effective synthetic chemical compound [8].

1). After the freeze-dries a total of $0.195 \mathrm{~g}$ powder was extracted from $6 \mathrm{~g}$ of crude propolis in $70 \% \mathrm{EtOH}$ (the extraction ratio was around $3.25 \%$ ). 
The extraction rate of crude propolis in different solvents

Table 1

\begin{tabular}{lccccccc}
\hline \multirow{2}{*}{ № } & \multicolumn{5}{c}{ Solvent } & \multicolumn{5}{c}{ Brix, \% } \\
\cline { 2 - 8 } & Name & Concentration, \% & $\mathbf{3 h}$ & $\mathbf{2 0 h}$ & $\mathbf{2 4 h}$ & $\mathbf{4 8 h}$ & $\mathbf{7 2 h}$ \\
\hline 1 & DDW & - & 0.1 & 4.0 & 2.0 & 5.1 & 2.0 \\
2 & EtOH & 10 & 0.3 & 4.1 & 3.3 & 2.7 & 0.3 \\
3 & EtOH & 20 & 2.0 & 3.0 & 2.1 & 1.5 & 1.1 \\
4 & EtOH & 30 & 1.5 & 2.0 & 2.0 & 2.1 & 1.0 \\
5 & EtOH & 40 & 1.6 & 2.1 & 2.2 & 2.2 & 1.1 \\
6 & EtOH & 50 & 2.8 & 3.1 & 2.9 & 3.0 & 2.8 \\
7 & EtOH & 60 & 3.4 & 3.6 & 3.5 & 3.6 & 3.6 \\
8 & EtOH & 70 & $\mathbf{4 . 0}$ & $\mathbf{4 . 0}$ & $\mathbf{5 . 0}$ & $\mathbf{4 . 4}$ & $\mathbf{4 . 7}$ \\
9 & EtOH & 80 & 5.0 & 5.5 & 4.6 & 4.0 & 4.4 \\
10 & EtOH & 96 & 3.9 & 3.9 & 4.9 & 4.0 & 4.5 \\
11 & MeOH & 99 & 4.0 & 4.1 & 4.4 & 4.0 & 4.0 \\
\hline
\end{tabular}

The constituents of two crude propolis samples are shown below (Table 2). The total moisture of crude propolis was $1.1 \%$ and $2.1 \%$, ash content was 1.3 and
$1.7 \%$ for the S1 and S2, respectively. The total fat and protein content in $\mathrm{S} 1$ was $67.8 \%$ and $0.8 \%$, while in $\mathrm{S} 2-69.3 \%$ and $1.05 \%$.

Table 2

\section{Contents percentage of constituents of Mongolian crude propolis}

\begin{tabular}{lcc}
\hline \multicolumn{1}{c}{ Contents, $\%$} & S1 (Northern part) & S2 (Central part) \\
\hline Moisture & 1.1 & 2.1 \\
Ash & 1.3 & 1.7 \\
Fat & 67.8 & 69.3 \\
Protein & 0.8 & 1.05 \\
\hline
\end{tabular}

The free amino acid content in propolis was determined by colorimetric assay and results showed that $1.21 \mu \mathrm{g} / \mathrm{mg}$ in samples from the northern part and $1.09 \mu \mathrm{g} / \mathrm{mg}$ in samples from the central part of
Mongolia. While the total amino acid content was determined by HPLC and 17 peaks detected for 17 amino acids (Table 3 ). The chromatogram with peaks and retention time is shown in Figure 1.

Table 3

Total amino acid determination

\begin{tabular}{cccccc}
\hline \multirow{2}{*}{ Amino acids } & \multicolumn{2}{c}{ Amount, $\mathbf{~ m g / g}$} & \multirow{2}{*}{ Amino acids } & \multicolumn{2}{c}{ Amount, mg/g } \\
\cline { 2 - 3 } & $\mathbf{S 1}$ & $\mathbf{S 2}$ & & S1 & S2 \\
\hline Asp & $\mathbf{0 . 6 8}$ & $\mathbf{1 . 2 4}$ & Meth & $\mathbf{1 . 9 0}$ & $\mathbf{2 . 6 2}$ \\
Thr & 0.42 & 0.74 & Ile & 0.70 & 1.00 \\
Ser & 0.56 & 1.05 & Leu & 0.24 & 0.30 \\
Glu & 0.95 & 1.98 & Tyr & 0.71 & 0.95 \\
Pro & 0.56 & 0.57 & Phe & 0.04 & 0.07 \\
Gly & 0.43 & 0.90 & His & 0.014 & 0.30 \\
Ala & 0.75 & 1.34 & Lys & - & 0.64 \\
Val & 0.60 & 0.78 & Arg & - & $\mathbf{0 . 8 1}$ \\
Cys & $\mathbf{0 . 0 3}$ & $\mathbf{0 . 1 7}$ & & & \\
\hline
\end{tabular}


As shown in Fig.1, first, the asparagine was detected with retention time within 13.044-13.072 min with the concentration of $0.68 \mathrm{mg} / \mathrm{g}$ and $1.24 \mathrm{mg} / \mathrm{g}$ in S1 and S2 samples, respectively. The last amino acid arginine was detected at 143.809-144.028 min with of concentration of $0.81 \mathrm{mg} / \mathrm{g}$ in S2.

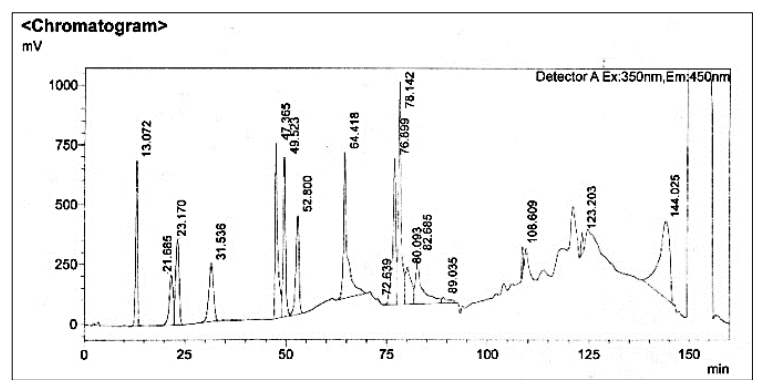

A. Sample from Northern part (S1)
The methionine was the most abundant amino acid in propolis with the amount of $1.90 \mathrm{mg} / \mathrm{g}$ and $2.62 \mathrm{mg} / \mathrm{g}$ $\mathrm{S} 1$ and $\mathrm{S} 2$ within the peak of $72.639-72.719 \mathrm{~min}$. The least amount of amino acid was cysteine in S1 with $0.03 \mathrm{mg} / \mathrm{g}$ and $0.17 \mathrm{mg} / \mathrm{g}$ in the $\mathrm{S} 2$ sample.

Figure 1. Chromatograms of total amino acids by HPLC

The total phenolics examined in TLC with system of toluene, methanol, acetone, and ammonia (50:40:8:2). Total 3 alkaloids detected with dragendorff reagent with brown color. On TLC foil

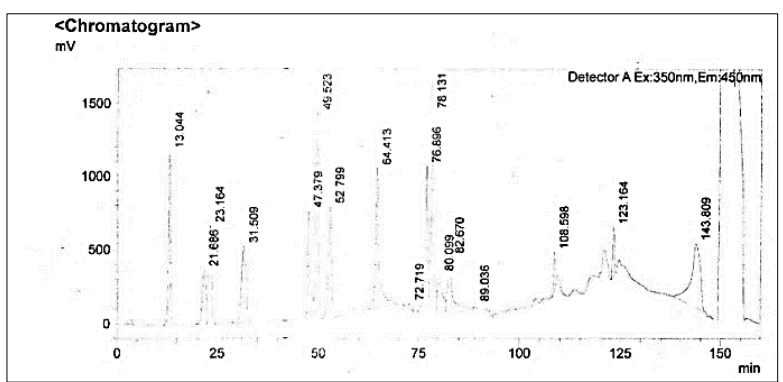

B. Sample from Central part (2)

yellow 2 points were detected with $5 \% \mathrm{H}_{2} \mathrm{SO}_{4}$, which means 2 types of phenolics were found in propolis samples.

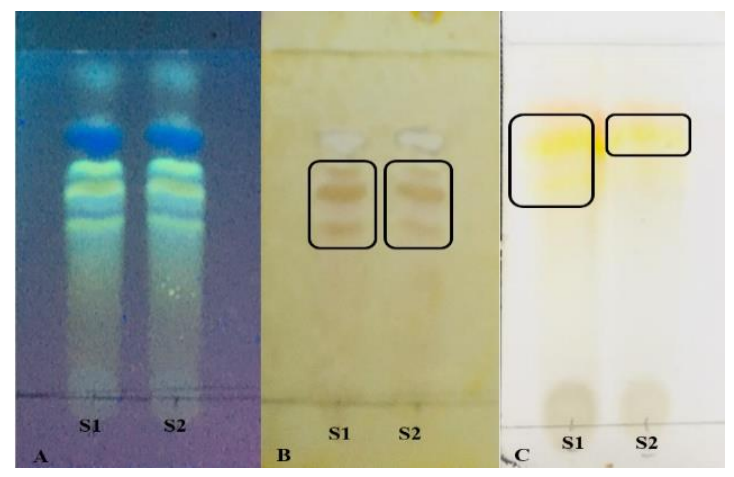

Figure 2. TLC results of total phenolics and alkaloids

TLC system: Toluene, Methanol, Acetone Ammonia (50:40:8:2). A-Total spots on 365nm, B-Alkaloids detected by dragendorff reagent, C-Phenolics detected by $5 \% \mathrm{H}_{2} \mathrm{SO}_{4}$

The results of the DPPH radical scavenging assay showed a high antioxidant effect with concentration increase. The highest data presented by the $\mathrm{S} 1$ sample at $5 \mathrm{mg} / \mathrm{ml}$ concentration with $85 \%$ and the highest result of S2 was $70 \%$ of the DPPH scavenging ratio.

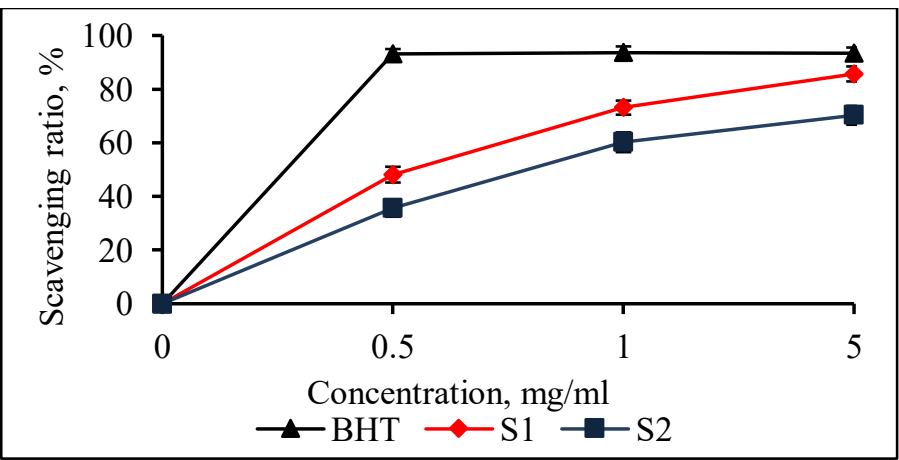

Figure 3. The DPPH radical scavenging assay

All values are expressed as the means $\pm \mathrm{SD}(\mathrm{n}=3$ ) 


\section{DISCUSSION}

In our study, we examined the content of propolis samples from northern (S1) and central parts (S1) of Mongolia. The results of the two samples were dissimilar and the data support the concept. The propolis extraction in $70 \% \mathrm{EtOH}$ gave the highest solute with $5 \%$ and the extraction ratio was around $3.25 \%$ after freeze-drying. For the best extraction method of propolis, other scientists also used $70 \%$ EtOH with different extractions ways to get the best result in bio-active components content [9]. The ash content was similar to Brazilian red, green and brown propolis samples, where the range of ash was 0.85 $3.3 \%$ [10] and our sample data was $1.3 \%$ in $\mathrm{S} 1$ and $1.7 \%$ in S2. However, the total protein and fat content were relatively different. The total protein of Mongolian propolis was low with a value of $0.8 \%$ and 1.05 in S1 and S2, respectively. In Brazilian propolis samples, the total amount of protein was in the range of $0.84-10.58 \%$ [10]. On the other hand, the fat content of our test samples illustrated moderate-high

\section{CONCLUSION}

In this study, the propolis samples collected from the central part of Mongolia showed higher results in every aspect with total moisture, ash, fat, and protein. However, overall samples from Mongolia showed a

\section{REFERENCE}

[1]P.Katarzyna, K.Kraśniewska, and G.Małgorzata, "Application of propolis in antimicrobial and antioxidative protection of food quality - A review," Trends in Food Science \& Technology, vol. 83, pp.53-62, 2018, doi.org/10.1016/j.tifs.2018.11.007

[2]Z.Ahangari, M.Naseri, and F.Vatandoost, "Propolis: Chemical Composition and Its Applications in Endodontics," Iran Endod J., vol. 13, pp. 285-29, 2018, doi.org/10.22037/iej.v13i3.20994

[3] R.Silva-Carvalho, F.Baltazar, and C.AlmeidaAguiar, "Propolis: A Complex Natural Product with a Plethora of Biological Activities That Can Be Explored for Drug Development," Evid Based Complement Alternat Med., May 27, 2015, doi.org/10.1155/2015/206439 value with $67.8 \%$ and $69.3 \%$ comparing with $45 \%$ $74 \%$ [10]. The amino acid content in propolis samples was dissimilar with comparing with propolis from different origins. The propolis from California, USA had the highest concentration in arginine $34.3 \%$ and proline 19.5\% [11]; while Turkey's propolis had a great value of leucine $332 \mathrm{mg} / 100 \mathrm{~g}$ and proline 301 $\mathrm{mg} / 100 \mathrm{~g}$ [12]. In Mongolian propolis samples, the highest data demonstrated methionine with $1.90 \mathrm{mg} / \mathrm{g}$ and $2.62 \mathrm{mg} / \mathrm{g}$ in S1 and S2, respectively. The high antioxidant effect measured by DPPH radical scavenging activity assay illustrated the maximum inhibition was at $5 \mathrm{mg} / \mathrm{ml}$ concentration with $\mathrm{S} 1$ $85.7 \%$ and S2 $70.2 \%$. The ethanolic of western Romanian propolis samples also showed a high antioxidant effect at $5 \mathrm{mg} / \mathrm{ml}$ from $79.57-92.5 \%$ on DPPH assay. The high antioxidant activity is possibly due to phenolic compounds found in propolis samples [13].

moderate-high fat amount comparing with other references. These differences are possibly due to plant origins of the regions where propolis samples were collected.

[4]L.G.Dias, A.P.Pereira, and L.M.Estevinho, "Comparative study of different Portuguese samples of propolis: pollinic, sensorial, physicochemical, microbiological characterization and antibacterial activity," Food Chem Toxicol., vol. 50, pp. 4246-4253, 2012, doi.org/10.1016/j.fct.2012.08.056

[5] S.S.Nielsen, Food Analysis. $4^{\text {th }}$ edition, p.123, 2010

[6]H.K.Maehre, L.Dalheim, G.K.Edvinsen, E.O.Elvevoll and I.J.Jensen, "Protein Determination-Method Matters," Foods. vol. 7, pp.5, 2018, doi.org/10.3390/foods7010005

[7] Sh.Ramnath, S.Venkataramegowda, "Chemical Composition of Bee Propolis Collected from Different Regions in India by GCMS Analysis," International Journal of Pharmacognosy and Phytochemistry, vol. 301, pp. 1319-1328, 2015.

[8] D.Huang, B.Ou, and R.L.Prior, "The chemistry behind antioxidant capacity assays," J Agric Food Chem., vol. 53, pp. 1841-1856, 2005, doi.org/10.1021/jf030723c 
[9]T.Trusheva, D.Trunkova, and V.Bankova, "Different extraction methods of biologically active components from propolis5 a preliminary study," Chem. Cent. J. vol. 1, pp. 13, 2016, doi.org/10.1186/1752-153X-1-13

[10] B.A.Machado and et al., "Chemical Composition and Biological Activity of Extracts Obtained by Supercritical Extraction and Ethanolic Extraction of Brown, Green and Red Propolis Derived from Different Geographic Regions in Brazil," PloS One. Jan. 8, 2016, doi.org/10.1371/journal.pone.0145954

[11] S.Sibel, "Amino acid and vitamin content of propolis collected by native Caucasian honeybees," J. Apic. Sci., vol. 60, Dec. 08, 2016, doi.org/10.1515/jas-2016-0021

[12] J.Shani, " Free amino acids in bee hive product (propolis) as indetified and quantified by gas-liquid chromatography, "Pharmacol. Res. Commun., vol.18, 1986, doi.org/10.1016/00316989(86) $90146-3$

[13] A.Duca et al., " Identification of Resveratrol as Bioactive Compound of Propolis from Western Romania and Characterization of Phenolic Profile and Antioxidant Activity of Ethanolic Extracts," Molecules, vol. 24(18), pp. 3368, 2019, doi.org/10.3390/molecules24183368 